\title{
The Morphology of Proteus Bacteriophages
}

\author{
By O. W. PROZESKY, H. C. DE KLERK AND J. N. COETZEE \\ Department of Microbiology, University of Pretoria, \\ Pretoria, South Africa
}

(Received 1 March 1965)

\begin{abstract}
SUMMARY
The morphology of 28 bacteriophages active on members of the ProteusProvidence group of organisms was examined by a negative staining technique. Examples of the 'T-even', T3 and P22 morphologies were encountered as well as phages with non-contractile cross-striated tails resembling a group of coliphages. Others resemble staphylococcal and pseudomonas phages. Two phages $(9,7479)$ with octahedral capsids were encountered. A temperate Proteus mirabilis phage (12/57) and a temperate $P$. morganii phage (10041/2815) differ from phage $\mathbf{P} 22$ in that they possess collars. A $\boldsymbol{P}$. rettgeri phage $(7480 \mathrm{~b})$ is unique in that it possesses a head with a regular hexagonal outline, a collar and a non-contractile tail while a Providence phage (9266) is believed to be the largest phage active on Gram-negative bacteria.
\end{abstract}

\section{INTRODUCTION}

The morphology of Proteus bacteriophages was first examined by Ruska (1943, 1950). He examined shadow-cast preparations and recorded the dimensions of tadpole-shaped phages. Coetzee (1958) examined shadow-cast preparations of phages active on Proteus vulgaris and $\boldsymbol{P}$. mirabilis. They were also tadpole shaped. In a paper on defective lysogeny Taubeneck (1963) published photographs of shadow-cast preparations of a tadpole-shaped phage derived from a lysogenic strain of $\boldsymbol{P}$. mirabilis. Other illustrations in the paper show tail cores surrounded by contractile sheaths adsorbed to $\boldsymbol{P}$. mirabilis and $\boldsymbol{P}$. vulgaris strains. These tails were liberated by defective lysogenic strains and no head structures were visible.

In the family Enterobacteriaceae bacteria of the Proteus and Providence groups share the distinction that they alone possess a phenylalanine deaminase (Shaw \& Clarke, 1955). They display many intra- and inter-group differences (Ewing, 1958) and their classification is uncertain. Rauss (1962) would allocate them tribal rank in the family with genera Proteus, Morganella, Rettgerella and Providencia. Topley \& Wilson's Principles (1964) recognize 'vulgaris, mirabilis, morganii and rettgeri' species in a genus Proteus of the tribe Enterobacterieae. They do not commit themselves on the position of the Providence group. Kauffmann (1951) has combined 'mirabilis' and 'vulgaris ' strains in a species 'hauseri'. Falkow, Ryman \& Washington(1962) suggest that $\boldsymbol{P}$. morganii is distinct genetically, possessing a guanine + cytosine molar content of $50 \%$, compared with other Proteus and Providence strains, where content is about $40 \%$. We decided to study the structure of phages active on the above organisms as an approach to the taxonomy of both the phages and their hosts. 


\section{METHODS}

Bacteriophages and host organisms. Phages were isolated from sewage by the enrichment technique of Adams (1959) or were derived from lysogenic strains, spontaneously or by ultraviolet induction. All but 4 of the phages have been used in other investigations and are listed in Table 1 together with the method of isolation, indicator host and reference to the literature. Sewage phages 50, 67 b and

Table 1. Sources of bacteriophages

\begin{tabular}{|c|c|c|c|}
\hline Phages & Isolation & Indicator & Reference \\
\hline \multicolumn{4}{|l|}{ Proteus hauseri } \\
\hline $\mathbf{9}$ & Sewage & P. vulgaris 9 ) & \\
\hline 15 & Sewage & P. vulgaris 15 & Coetzee, 1958 \\
\hline 65 & Sewage & P. vulgaris 65 ) & \\
\hline $67 \mathrm{~b}$ & Sewage & P. vulgaris 67 & See Methods \\
\hline 78 & Sewage & P. vulgaris 78 & \\
\hline 12 & Sewage & P. mirabilis 12 & \\
\hline 14 & Sewage & P. mirabilis 14 & coeczee, 1808 \\
\hline 57 & Sewage & P. mirabilis 57 & \\
\hline $34 / 13$ & P. mirabilis 84 & P. mirabilis 13) & \\
\hline $12 / 57$ & P. mirabilis 12 & P. mirabilis $\mathbf{5 7}\}$ & Coetzee \& Sacks, 1959, 1960 $a, b$ \\
\hline$\frac{\frac{2 \pi}{25}}{25} / 14$ & P. mirabilis 24, 25 & P. mirabilis 14) & \\
\hline 13 vir & P. mirabilis 13 & P. mirabilis 13 & See Methods \\
\hline \multicolumn{4}{|l|}{ P. morganii } \\
\hline $\mathbf{5 0}$ & Sewage & P. morganii м 50 & See Methods \\
\hline $\mathbf{5 8 4 5}$ & Sewage & NCTC 5845 & \\
\hline $10041 / 2815$ & NCTC 10041 & NCTC 2815 & Coetzee, $1963 a$ \\
\hline 47 & $\mathbf{M 4 7}$ & $\left.\begin{array}{c}P . \text { morganii } \\
\text { м } 235\end{array}\right\}$ & COELET, 1900 a \\
\hline \multicolumn{4}{|l|}{ Providence } \\
\hline 9248 & Sewage & NCTC 9248 ) & \\
\hline 9266 & Sewage & NCTC 9266 & \\
\hline $9211 / 9295$ & NCTC 9211 & NCTC 9295 & Coetzee, $1963 b$ \\
\hline 9213/9211 a, b & NCTC 9213 & NCTC 9211 & \\
\hline $9000 / 9402$ & NCTC 9000 & NCTC 9402 & \\
\hline \multicolumn{4}{|l|}{ P. rettgeri } \\
\hline 8893 & Sewage & NCTC 8893$\}$ & Coetzee, $1963 c$ \\
\hline 7480 & Sewage & NCTC 7480$\}$ & Coelzet, $1800 \mathrm{C}$ \\
\hline $7480 \mathrm{~b}$ & Sewage & NCTC 7480 & See Methods \\
\hline 7479 & Sewage & NCTC 7479 ) & \\
\hline $7478 / 325$ & NCTC 7478 & R325 & Coetzee, $1963 c$ \\
\hline $7476 / 322$ & NCTC 7476 & R322 & \\
\hline
\end{tabular}

7480 b productively lyse Proteus morganii strain M 50, $P$. vulgaris strain 67 and $\boldsymbol{P}$. rettgeri NCTC7480 respectively. Phage 13 vir is present in plaques which appear spontaneously on cultures of $\boldsymbol{P}$. mirabilis strain 13. Organisms of this strain cannot be freed of the phage by suspension in high-titre phage antiserum, and this phage is therefore regarded as a virulent mutant of a temperate phage of strain 13. The temperate phage has not yet been demonstrated. The general phage techniques were those of Adams (1959).

Media. The nutrient agar was that of Adams (1959) and the broth was that of Coetzee \& Sacks $(1960 c)$.

Electron microscopy. High-titre phage lysates of sewage phage were prepared by infecting young aerated broth cultures from single plaques. Temperate phages were 
prepared by the modification (Adams, 1959) of the double-agar-layer method of Hershey, Kalmanson \& Bronfenbrenner (1943). The lysates were purified and concentrated by differential centrifugation (de Klerk, Coetzee \& Fourie, 1965). The purified phages (plaque-forming titres about $1 \times 10^{11} / \mathrm{ml}$.) were suspended in

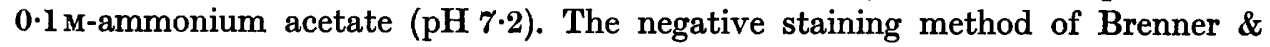
Horne (1959) was used. Phage suspensions in neutral potassium phosphotungstate were mounted on carbon support films by the spreading technique (Bradley, 1962) and examined with a Philips EM 200 electron microscope. In the absence of spontaneous contraction of tail sheaths, hydrogen peroxide $(3 \%, v / v)$ and ethyl alcohol $(10 \%, v / v)$ were added to phage suspensions to cause possible sheath contraction (Kellenberger \& Arber, 1955).

\section{RESULTS}

Dimensions of the bacteriophages examined are listed in Table 2.

Table 2. Dimensions (in $A$ ) of Proteus bacteriophages

\begin{tabular}{|c|c|c|c|c|c|}
\hline \multirow{2}{*}{ Phage } & \multirow[b]{2}{*}{ Head* } & \multicolumn{2}{|c|}{ Tail } & \multirow{2}{*}{$\begin{array}{c}\text { Core } \\
\text { width }\end{array}$} & \multirow{2}{*}{$\begin{array}{l}\text { Overall } \\
\text { length }\end{array}$} \\
\hline & & Length & Width & & \\
\hline \multicolumn{6}{|l|}{ Proteus hauseri } \\
\hline 15 & 518 & 148 & 222 & - & 666 \\
\hline 34/13 & 630 & 167 & 204 & - & 797 \\
\hline 65 & 518 & 148 & 222 & - & 666 \\
\hline $12 / 57$ & 589 & 185 & 204 & - & 774 \\
\hline 9 & 826 & 1837 & 89 & - & 2663 \\
\hline 13 vir & 600 & 1019 & 167 & 60 & 1619 \\
\hline 57 & 619 & 882 & 178 & $\mathbf{5 6}$ & 1501 \\
\hline $67 \mathrm{~b}$ & 589 & 981 & 174 & 74 & 1570 \\
\hline 78 & 611 & 889 & 163 & 60 & 1500 \\
\hline 12 & 593 & 2163 & 115 & - & 2756 \\
\hline 14 & 660 & 2045 & 115 & - & 2705 \\
\hline$\frac{84}{25} / 14$ & $715 \times 604$ & 1715 & 108 & - & 2430 \\
\hline \multicolumn{6}{|l|}{ P. morganii } \\
\hline 50 & $970 \times 670$ & 1252 & 159 & 52 & 2222 \\
\hline 5845 & $1022 \times 763$ & 1252 & 156 & 74 & 2274 \\
\hline $10041 / 2815$ & 544 & 182 & 167 & $\longrightarrow$ & 726 \\
\hline 47 & 556 & 1481 & 85 & - & 2037 \\
\hline \multicolumn{6}{|l|}{ Providence } \\
\hline 9248 & 611 & 185 & - & 一 & 796 \\
\hline 9266 & $1193 \times 822$ & 2152 & 248 & 96 & $\mathbf{3 3 4 5}$ \\
\hline $9213 / 9211 \mathrm{a}$ & 626 & 1696 & 137 & - & 2322 \\
\hline $9213 / 9211 b$ & 608 & 152 & 204 & - & 760 \\
\hline $9211 / 9295$ & 533 & 148 & 196 & - & 681 \\
\hline $9000 / 9402$ & 682 & 2304 & 148 & - & 2986 \\
\hline \multicolumn{6}{|l|}{ P. rettgeri } \\
\hline 8893 & $926 \times 741$ & 1296 & 178 & 74 & 2222 \\
\hline 7480 & 634 & 2185 & 126 & - & 2819 \\
\hline $7480 \mathrm{~b}$ & 367 & 330 & 63 & - & 697 \\
\hline 7479 & 737 & 1852 & 85 & - & 2589 \\
\hline $7478 / 325$ & 604 & 1741 & 115 & 一 & 2345 \\
\hline $7476 / 322$ & 583 & 1600 & 77 & - & 2133 \\
\hline
\end{tabular}

* Dimensions between apices are given, or apex to tail-joint and width. Figures are the mean of 8 to 12 measurements. 


\section{Phages active on Proteus hauseri strains}

Phages 15, 34/13, 65. (Pl. 1, figs. 1, 2.) These are similar in morphology. Phages 65 and 34/13 are presented. The heads have hexagonal outlines and attached to one of the angles by means of a short neck is a base-plate with a number of pins. These phages resemble salmonella phage P22 (Anderson, 1960) and pseudomonas phage $12 \mathrm{~B}$ (Bradley, $1963 a$ ) but phages 15 and 65 are slightly smaller.

Phage 12/5\%. (Pl. 1, fig. 3.) This phage resembles those just mentioned but possesses a delicate collar about $200 \AA$ wide, around the short neck. No tail fibres were seen.

Phage 9. (Pl. 1, fig. 4.) The head of this phage is large, hexagonal in outline and octahedral in shape. The tail is thin, cross-striated, non-contractile and ends in a point with tail fibres. It resembles pseudomonas phage 24 (Bradley, 1963 $a$ ), phage $1 \mathrm{C}$ (Bradley, 1962) and phages F1 (Bradley, 1963b) and WAK/2 (Bradley, 1964).

Phages 13 vir, 5\%, 67b, 78. (Pl. 1, figs. 5, 6, 7.) These phages have a similar morphology and 13 vir, 57 and 78 are shown. The head is regular hexagonal in plan view. The tail consists of a core surrounded by a contractile sheath to which is attached an inconspicuous base-plate, probably with 6 prongs. Cross-striations are visible on some of the sheaths with a periodicity of about $40 \AA$. These phages resemble Vi phage 1 (Bradley \& Kay, 1960) although their heads are smaller.

Phages 12, 14. (Pl. 1, fig. 8.) These phages are similar and correspond to the group of 'smaller phages without contractile tails' of Bradley (1963b). Phage 12 is shown. Their heads are polygonal and often hexagonal in outline. The tails are non-contractile and markedly cross-striated with a periodicity of about $40 \AA$. A small bundle of fibres is present at the tail tip.

Phage $\frac{24}{25} / 14$. (Pl. 1, fig. 9.) This phage has a polyhedral head slightly longer than wide which closely resembles that of phage $\mathrm{ZG} / 3 \mathrm{~A}$ (Bradley, 1964). It has a noncontractile tail with cross-striations about $30 \AA$ apart. No tail fibres have been observed.

\section{Phages active on strains of Proteus morganii}

Phages 50, 5845. (Pl. 1, fig. 10; Pl. 2, figs. 11, 12.) These phages are similar in shape. The dimensions and appearance of the heads suggest that they may be bipyramidal hexagonal prisms and the tails consist of cores surrounded by crossstriated contractile sheaths. A base-plate with pins moves with the sheath. Tail fibres are present and in some photographs they form a fibrous network which extends to the collar (Bradley, 1963 b). The collars have a width of $360 \AA$ and a periodicity of the sheaths of this group is about $40 \AA$. In Pl. 2, fig. 11, is a separate rosette-shaped structure which may be either a base-plate or a collar. These phages resemble phage $\mathbf{T} 4$, which is reported to possess a bipyramidal hexagonal head (Bradley, 1963b).

Phage 10041/2815. (Pl. 2, fig. 13.) This phage is similar to but slightly smaller than $P$. hauseri phage 12/57. The collar above the base-plate can be clearly seen on one of the phages in the figure. No tail fibres have been observed.

Phage 4\%. (Pl. 2, figs. 15, 18.) This phage has a head with a hexagonal outline. The tail is non-contractile and cross-striated. It has no neck or collar, tail fibres have not been identified and it resembles the SBL group of typhoid phages (Bradley, $1963 b$ ). 
Phages active on Providence strains

Phage 9248. (Pl. 2, fig. 14.) The head of the phage is polyhedral and hexagonal in plan view. It has a wedge-shaped tail attached to one corner and resembles coliphage T3. It also resembles brucella phages (Brinley-Morgan, Kay \& Bradley, 1960; McDuff, Jones \& Wilson, 1962) and a group of pseudomonas phages (Bradley, $1963 a)$.

Phage 9266. (Pl. 2, figs. 16, 17.) This large phage has a head which is hexagonal in outline and resembles those of the $\mathrm{T}$-even phages. The tail core is surrounded by a contractile sheath with cross-striations. No base-plate is evident. Attached to the tail sheath and visible in the contracted state (Pl. 2, fig. 16) are 6 short spikes and a tangled mass of fibres. It has a neck but no collar.

Phage 9213/9211a. (Pl. 2, fig. 19.) The phage has a head with a regular hexagonal outline in certain views. The tail is non-contractile, has cross-striations and ends in a rosette-shaped structure. It resembles staphylococcal phages 187, 52 (Bradley, $1963 a$ ) and pseudomonas phages Pc, Pz (Bradley \& Kay, 1960).

Phages 9213/9211b, 9211/9295. (Pl. 3, figs. 20, 21). These phages resemble the $P$. hauseri groups 34/13, 15, 65 and 12/57 and the $P$. morganii phage 10041/2815. On occasions a rod $30-40 \AA$ wide which projects about $150 \AA$ beyond the baseplate was seen, but could not be consistently demonstrated. No tail fibres were seen.

Phage 9000/9402. (Pl. 3, fig. 23.) The outline of the head is a regular hexagon. It has a long non-contractile tail with cross-striations and some fibres at the tip. This phage is slightly longer than the $P$. hauseri phages 12, 14, but smaller than the $C_{1}$, $\mathrm{F}_{1}$ group of coliphages (Bradley, 1963b).

\section{Phages active on strains of Proteus rettgeri}

Phage 8893. (Pl. 3, fig. 26.) The structure is similar to $P$. morganii phages 50, 5845 .

Phage 7480. (Pl. 3, fig. 22.) This phage is similar to Providence phage 9000/9402.

Phage 7480b. (Pl. 3, fig. 25.) The head has a regular hexagonal outline. A short tail is attached to one corner by a neck which is surrounded by a collar. The tail could not be made to contract by the methods used and cross-striations were not seen. Despite repeated efforts the detailed structure of the tail-tip could not be resolved. The collar is $100 \AA$ wide.

Phage 7479. (Pl. 3, fig. 24.) This phage resembles $P$. hauseri phage 9 although the octahedral head is slightly smaller.

Phage 7478/325. (Pl. 3, fig. 27.) This phage resembles $P$. hauseri phage 12, 14, $P$. morganii phage 47 , Providence phage $9000 / 9402$ and $P$. rettgeri phage 7480 . The dimensions are similar to those of T5 (Bradley \& Kay, 1960).

Phage 7476/322. (Pl. 3, fig. 28.) The phage head is hexagonal in outline. The tail is thin, cross-striated and measures about $30 \AA$ less in width than tails of the SBL group (Bradley \& Kay, 1960).

Many of the capsids have an uneven rough appearance suggestive of arrays of capsomeres (Bradley, 1964) but neither their shape nor their packing arrangements could be determined. Apart from those whose heads are obviously octahedral, the head shapes of the phages could not be determined. We have indicated those which may have bipyramidal shapes and the remainder are possibly icosahedra. 


\section{DISCUSSION}

Undescribed varieties of phage have been found. The Proteus mirabilis transducing phage 12/57 differs from its salmonella counterpart P22 in that it has a delicate collar. The same applies to $P$. morganii phage $10041 / 2815$. Phage $7480 \mathrm{~b}$ is unique in that it has a collar, a non-contractile tail and a head with a regular hexagonal outline. Phage ZG/3 A described by Bradley (1964) is similar, but has a bipyramidal prismatic head. The overall dimensions of phage 9266 are larger than those of phage P1 (Anderson, 1960) (which is described as the largest phage yet examined (Hayes, 1965)) though some staphylococcal phages have longer tails (Bradley \& Kay, 1960). Phage 13 vir has a unique morphology for a phage derived from a lysogenic bacterium. The nearest to it are phages P1, P2 (Anderson, 1960), which are much larger, lack tail pins and have less conspicuous tail fibres. The original lysate of phage 9213/9211 (Coetzee, 1963b) was thought to be pure, but it has yielded two morphological types. There is a possibility that one of the phages may be derived from the indicator strain NCTC 9211 although this strain has not been proved lysogenic.

It is not known how the P22 group of phages infect their hosts (Anderson, 1960). The finding here of phages which resemble P22 but have collars may eventually cast light on the process. Tail fibres were never observed in these phages. The nature of the structure which projects beyond the base plates of phages $9213 / 9211 \mathrm{~b}$ and $\mathbf{9 2 1 1 / 9 2 9 5}$ is not known. It could not always be demonstrated and may be nucleic acid.

Providence phage 9248 resembles coliphage T3. Its head shape could not be established but it may be octahedral like that of phage T3 (Bradley, 1963 $b$ ). Two other phages $(9,7479)$ of this series possess octahedral capsids. Caspar \& Klug (1962) have cast doubt on the octahedral shapes of phage capsids but Bradley $(1963 b ; 1964)$ has clearly demonstrated such capsids among coliphages.

Good correlation between the morphological and serological types of phages have been recorded (Bradley, 1963 $a$; de Klerk, Coetzee \& Theron, 1963; de Klerk et al. 1965). Phages 15,65, which are morphologically identical, are related serologically but the identical structural types 57, 78 differ serologically and in other aspects (Coetzee, 1958). The bacteriophages studied show considerable morphological variation and identical types grow on representatives of most of the groups of organisms. This lack of morphological specificity is a great problem in bacteriophage taxonomy (Dawson, Smillie \& Norris, 1962; Bradley, 1963b). Results also diminish the hope of finding a particular morphological type with a predilection for one or other of these groups of organisms like that of the RNA and filamentous phages for male strains of Escherichia coli (Bradley, 1964).

One of us (J.N.C.) is in receipt of a grant from the South African Council for Scientific and Industrial Research.

\section{REFERENCES}

Adams, M. H. (1959). Bacteriophages. New York: Interscience Publishers Inc.

Anderson, T. F. (1960). On the fine structure of the temperate bacteriophages P 1, P 2 and P22. Proc. Eur. Reg. Conf. Electron Microscopy, Delft, 2, 1008. 
Bradley, D. E. (1962). A study of the negative staining process. J. gen. Microbiol. 29, 503.

Bradley, D. E. (1963a). The structure of some Staphylococcus and Pseudomonas phages. J. Ultrastruct. Res. 8, 552.

Bradley, D. E. (1963b). The structure of coliphages. J. gen. Microbiol. 31, 435.

BradLEy, D. E. (1964). The structure of some bacteriophages associated with male strains of Escherichia coli. J. gen. Microbiol. 35, 471.

Bradley, D. E. \& KAy, D. (1960). The fine structure of bacteriophages. J. gen. Microbiol. 23, 553.

Brenner, S. \& Horne, R. W. (1959). A negative staining method for high resolution electron microscopy of viruses. Biochim. biophys. Acta, 34, 103.

Brinley-Morgan, W. J., Kay, D. \& Bradley, D. E. (1960). Brucella bacteriophage. Nature, Lond. 188, 74.

Caspar, D. L. D. \& Kuug, A. (1962). Physical principles in the construction of regular viruses. Cold Spr. Harb. Symp. quant. Biol. $27,1$.

Coetzee, J. N. (1958). The characterization of a series of Proteus bacteriophages. S. Afr. J. Lab. clin. Med. 4, 147.

Coetzee, J. N. (1963a). Host-range of Proteus morganii bacteriophages. Nature, Lond. $199,827$.

Coetzee, J. N. (1963b). Lysogeny in Providence strains and the host-range of Providence bacteriophages. Nature, Lond. 197, 515.

Coetzee, J. N. $(1963 c)$. Lysogeny in Proteus rettgeri and the host-range of $P$. rettgeri and P. hauseri bacteriophages. J. gen. Microbiol. 31, 219.

Coetzee, J. N. \& SACKs, T. G. (1959). Lysogeny in the genus Proteus. Nature, Lond. 184, 1340 .

Coetzee, J. N. \& SACks, T. G. $(1960 a)$. Lysogeny in the genus Proteus. I. Incidence of lysogenic strains. S. Afr. J. Lab. clin. Med. 6, 123.

Coetzee, J. N. \& SACKs, T. G. (1960b). Transduction of streptomycin resistance in Proteus mirabilis. J. gen. Microbiol. 23, 445.

Coetzee, J. N. \& Sacks, T. G. $(1960 c)$. Morphological variants of Proteus hauseri. J. gen. Microbiol. 23, 209.

Dawson, I. M., Smillie, E. \& Norris, J. R. (1962). The morphology of Bacillus cereus bacteriophages. J. gen. Microbiol. 28, 517.

Ewing, W. H. (1958). The nomenclature and taxonomy of the Proteus and Providence groups. Int. Bull. bact. Nomencl. 8, 17.

Falkow, S., Ryman, I. R. \& Washington, O. (1962). Deoxyribonucleic acid base composition of Proteus and Providence organisms. J. Bact. 83, 1318.

HAYEs, W. (1965). The Genetics of Bacteria and their Viruses. Oxford: Blackwell Scientific Publications.

Hershey, A. D., Kalmanson, G. R. \& Bronfenbrenner, J. (1943). Quantitative methods in the study of the phage-antiphage reaction. J. Immunol. 46, 267.

Kauffmann, F. (1951). Enterobacteriaceae. Copenhagen: Einar Munksgaard.

Kellenberger, E. \& Arber, W. (1955). Die Struktur des Schwanzes der Phagen T2 und T4 und der Mechanismus der irreversiblen Adsorption. Z. Naturf. 10 b, 698.

De Klerk, H. C., Coetzee, J. N. \& Fourie, J. T. (1965). The fine structure of Lactobacillus bacteriophages. J. gen. Microbiol. 38, 35.

de Klerk, H. C., Coetzee, J. N. \& Theron, J. J. (1963). The characterization of a series of Lactobacillus bacteriophages. J. gen. Microbiol. 32, 61 .

McDuFf, C. R., Jones, L. M. \& Wilson, J. B. (1962). Characteristics of brucellaphage. J. Bact. 83, 324.

RAuss, K. (1962). A proposal for the nomenclature and classification of the Proteus and Providence groups. Int. Bull. bact. Nomencl. 12, 53.

Ruska, H. (1943). Ergebnisse der Bakteriophagenforschung und ihre Deutung nach morphologischen Befunden. Erg. Hyg. 25, 437.

Ruska, H. (1950). Die Elektronenmikroskopie in der Virusforschung. In Handbuch der Virusforschung, 2. Ergänzungsband, p. 221. R. Doerr \& C. Hallauer. Wien: SpringerVerlag. 
Shaw, C. \& Clarke, P. H. (1955). Biochemical classification of Proteus and Providence cultures. J. gen. Microbiol. 13, 155.

Taubeneck, U. (1963). Über die Produktion biologisch aktiver Phagen-Schwänze durch einen defekt lysogenen Proteus mirabilis-Stamm. Z. Naturf. $18 b, 989$.

Topley and Wilson's Principles of Bacteriology and Immunity, (1964) 5th ed. Ed. by G. S. Wilson and A. A. Miles. London: Edward Arnold.

\section{EXPLANATION OF PLATES}

The magnification in all Figs. is $\times 270,000$. All phages in ammonium acetate and phosphotungstate. Figs. 1-9. Phages active on Proteus hauseri strains. Figs. 10-13, 15, 18: phages active on $P$. morganii strains. Figs. 14, 16, 17, 19-21, 23: phages active on Providence strains. Figs. 22, 24-28: phages active on $P$. rettgeri strains.

\section{Prate 1}

Fig. 1. Phage 65 .

Fig. 2. Phage 34/13.

Fig. 3. Phage 12/57.

Fig. 4. Phage 9.

Fig. 5. Phage 13 vir.

Fig. 6. Phage 78.

Fig. 7. Phage 57.

Fig. 8. Phage 12.

Fig. 9. Phage $\frac{24}{25} / 14$.

Fig. 10. Phage 50.

Figs. 11, 12. Phage 5845.

Plate 2

Fig. 13. Phage 10041/2815.

Fig. 14. Phage 9248.

Fig. 15. Phage 47 .

Figs. 16, 17. Phage 9266.

Fig. 18. Phage 47.

Fig. 19. Phage 9213/9211a.

Fig. 20. Phage 9213/9211 b.

Plate 3

Fig. 21. Phage 9211/9295.

Fig. 22. Phage 7480 .

Fig. 23. Phage 9000/9402.

Fig. 24. Phage 7479.

Fig. 25. Phage 7480 b.

Fig. 26. Phage 8893 .

Fig. 27. Phage 7478/325.

Fig. 28. Phage 7476/322. 
Journal of General Microbiology, Vol. 41, No. 1

Plate 1
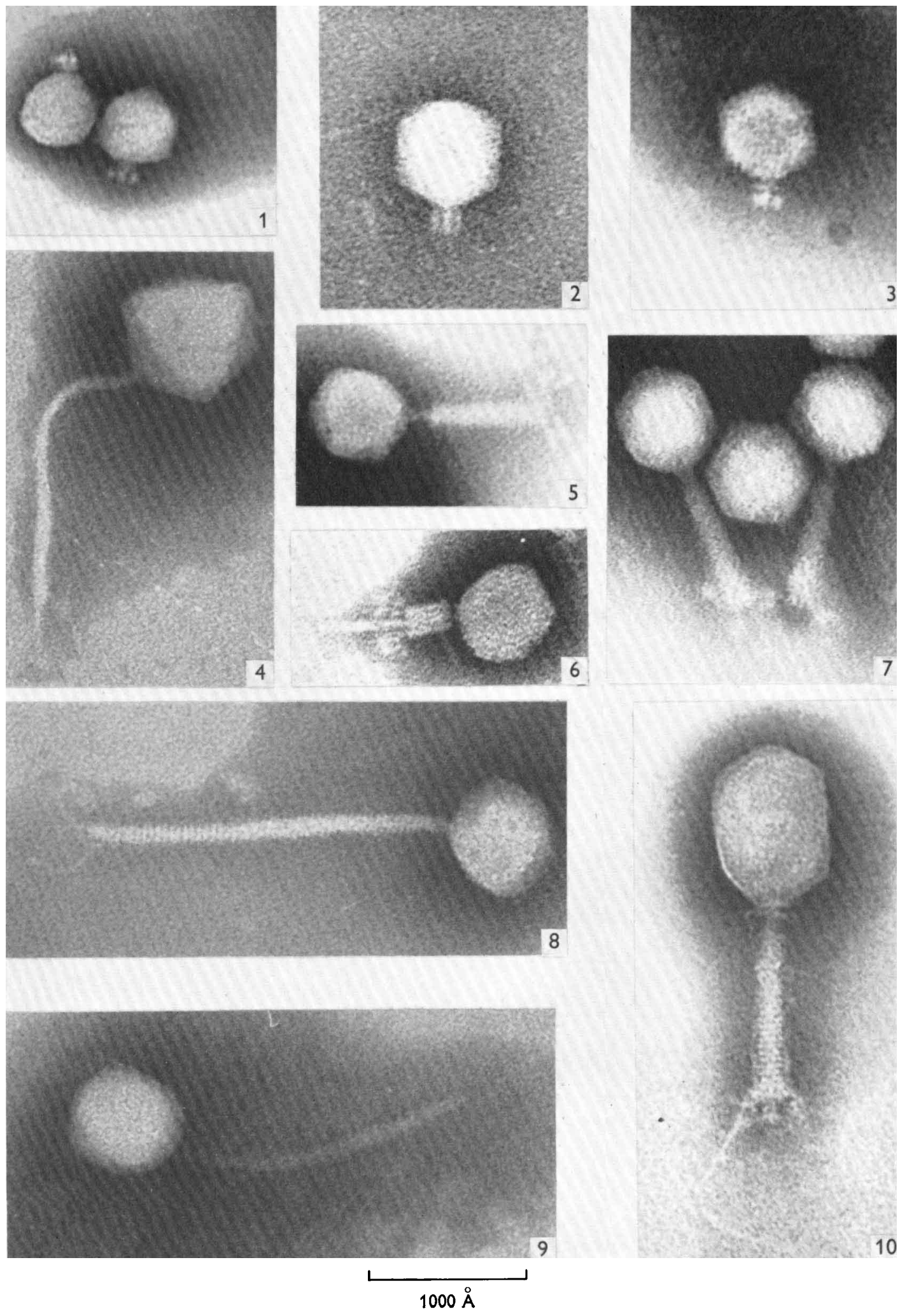

O. W. PROZESKY, H. C. DE KLERK AND J. N. COETZEE

(Facing p. 36) 

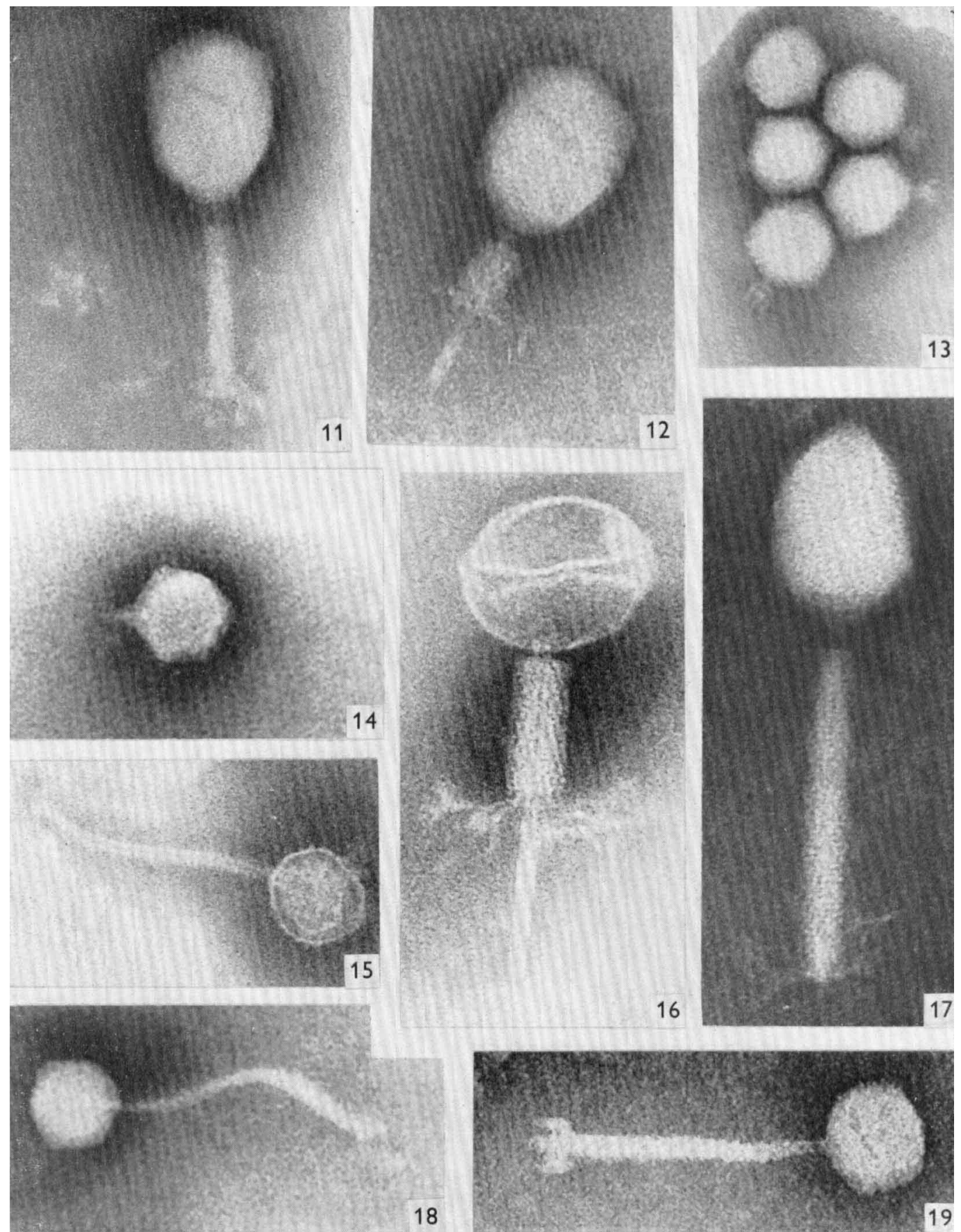

16

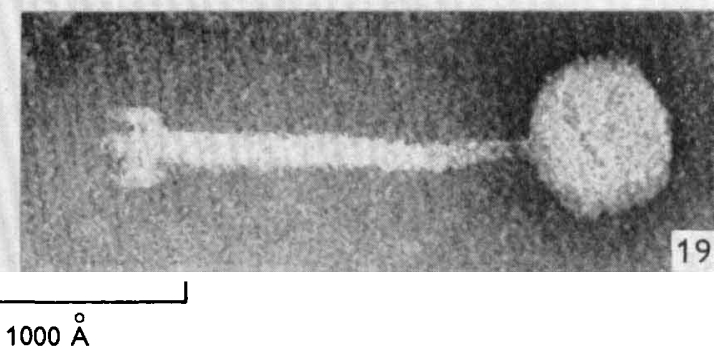

O. W. PROZESKY, H. C. DE KLERK and J. N. COETZEE 
Journal of General Microbiology, Vol. 41, No. 1

Plate 3
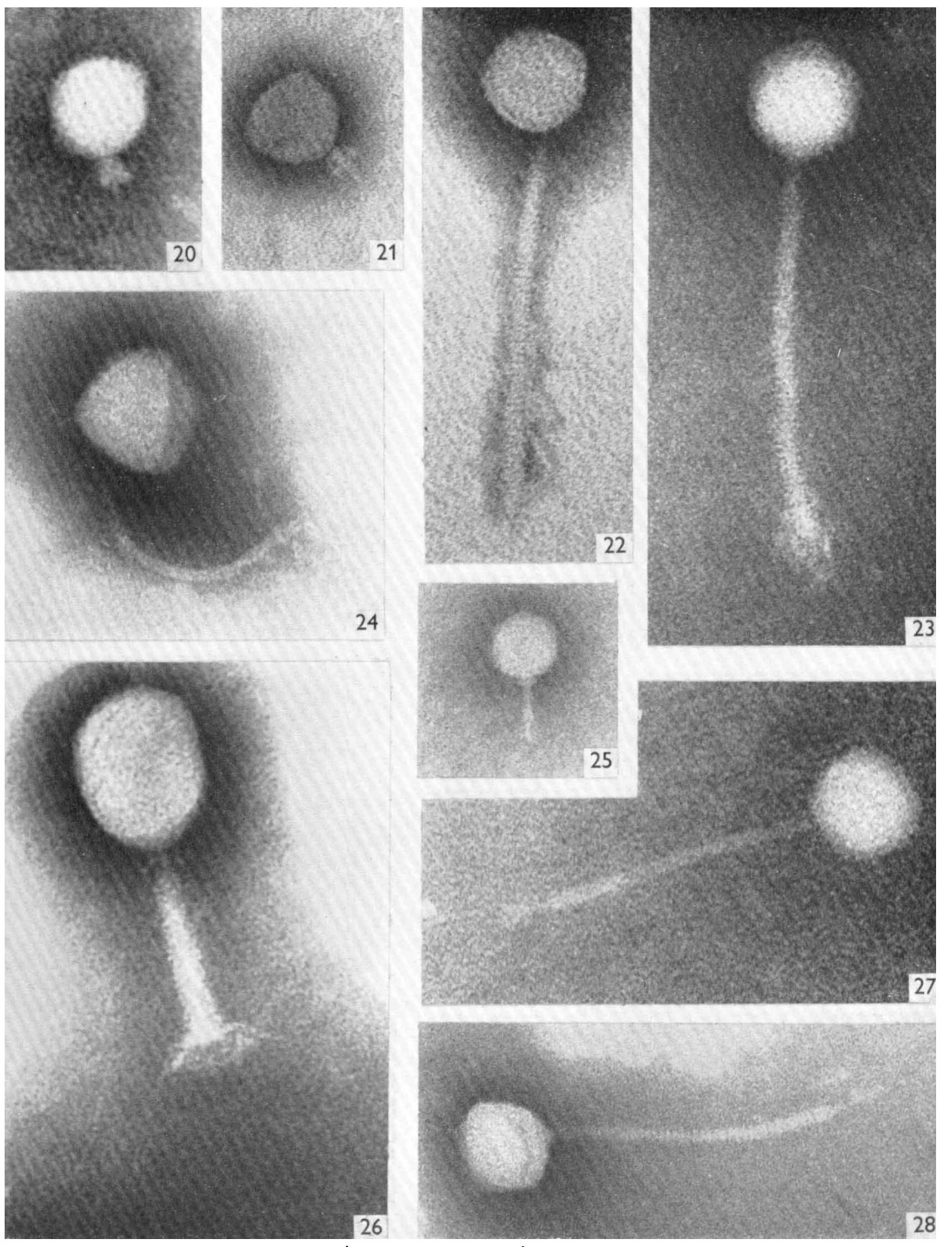

$1000 \AA$

O. W. PROZESKY, H. C. DE KLERK AND J. N. COETZEE 